\title{
Issues and Challenges among Young Entrepreneurs in Malaysia
}

\author{
Anis Amira Ab Rahman, Nik Maheran Nik Muhammad, Rikinorhakis Ridzwan \\ Universiti Malaysia Kelantan, 16100 Kota Bharu, Malaysia
}

\begin{abstract}
The involvement of young entrepreneurs has increase by 30 per cent from the total of 2.6 million entrepreneurs in 2014. This is due to the Malaysian government policy, continuous encouragement, increasing incentive and intervention strategies to develop this group of entrepreneur. However, in spite of all the supports, the percentage of failures among young entrepreneurs is still very frightening. Studies found that, there are only $20 \%$ of entrepreneurs survives and successful every year. In reality, they must have their own capabilities and it is depending on how they manage their business resources to success. Meanwhile, young entrepreneurs also need to noticed that it necessity for them to links with environment in order to strengthen access to markets and resources management. Hence, a thorough understanding of how youth entrepreneurs utilize their resources, thus how they bring contacts is important, because this will lead to the development of new tools, such as (1) tools for business to improve their innovation and growth processes and, (2) tools for governments to develop new policies to support and direct economic growth.
\end{abstract}

Keywords: Young entrepreneur, resources, resource orchestration, networking, entrepreneur success, entrepreneurship

\section{Introduction}

Young generation is an important asset to the economic development of a country. This is because they have a strong vitality that is needed for economic development. In addition, at a young age, they also still have the strength both mentally and physically [1]. Recently, young generation especially youth constitutes a large segment, which is 43 percent of the total population in Malaysia. Involvement of youth in entrepreneurship has become a major discussion among policy makers, educators and students throughout most developing countries [2]. Accordingly, youth had become one the important assets for many countries in sustaining the country's economy. Based on that, the Malaysian government, in order to create interest in entrepreneurship among youth, provides initial capital to start a venture. There are also an initiative had been launched by government to curb unemployment rate among graduates because many people in Malaysia involvement in entrepreneurship at the young age where this is an important for career development.

Meanwhile, youth efforts towards entrepreneurship during the economic crisis were praised by the government and society. Involvement of Malaysian people in entrepreneurship sector is rapidly increasing. Surprisingly, there are huge numbers of participation among those who aged less than 40 years old. This can be categorized as young entrepreneurs. They wanted to be involved in entrepreneurship because this activity will allows them to create values and provides them with the opportunity to turn their dreams into reality. Further studied by [2] have classified three important stages of young entrepreneurs; which are consists of teenagers with range aged between fifteen to nineteen years old (called pre-entrepreneurs), the budding entrepreneurs who consist of young adults with aged twenty to twenty five years old and the emergent entrepreneurs who consist of those aged twenty six to thirty five years old.

Along with the current situation is increasingly more challenging, the youth nowadays must have the proper job to ensure their success in the future [3]. Accordingly, the determination of appropriate careers among youth is very important to continue to live a more comfortable way. However, a major challenge faced by youth today is difficult to get a suitable job. This is due to the existence of growing competition and limited employment opportunities [4]. From that, the career that should be selected not only contributes for their economic development, but also will contribute to the economic development of their families, business, communities and country. Lately, a career as an entrepreneur is a career that often chosen by the younger generation because this career is indeed gives a good income [5].

\section{Issues And Challenges}

Becoming self-employed among youth is increasingly more relevant in the future. As Malaysia is a small country, youth can no longer rely on job opportunities. More jobs will become irrelevant in the future, thus making it tougher for people to secure jobs [6]. For example, based on Labour Force Statistics Malaysia in January 2015, the unemployment rate rose to $3.1 \%$ compared with $3.0 \%$ in December 2014 despite more jobs being created [7]. This was due mainly to an increase total of labour entered the marketplace. With that, Malaysian's government also has been long trying to increase the number of successful youth entrepreneurs 
nationwide and provide them with all the necessary support such as improvement of new and old products, improved technologies and existence of government authorized agents such as MARA, MARDI, FRIM and etc. [1]. Each person has their own reasons why they become entrepreneurs. For youth in Malaysia, the issues of unemployment have led them to find opportunities in self-employment. Although it is proven that there is a huge potential in current market and despite considerable government support and assistance in terms of grants, funding, provisions of training and consultative services, but many businesses operate by youth still fail and the failure rate remains high. As report by [8], the average number of bankruptcies among companies in Malaysia from 1998 until 2015 were 1,250 companies. From that, there were 107,306 cases of bankruptcies among entrepreneurs in Malaysia between January to April 2015, where 948 of them are youth [9]. For example, [10] found that there are about $20 \%$ of the young entrepreneurs survives and successful in markets every year. This proved that the success rates among them in Malaysia are still at a low level, and do not reach the target. In identifying whether they are really successful in their career of business, youth entrepreneurs must contribute to the economic development which is a reference to the economic development of individuals, organizations and society.

Furthermore, study by [11] found that many of young entrepreneurs can only survive in a short period not only because of their young age and the ability to manage business resources, but they also does not have a network of industrial cooperation with experienced people. In a multi-ethnic country like Malaysia, lack of exposure in term of managing and utilising resources from various sources like from their own resources, from cultural orientation, economic conditions and political linkages are often cited as factors that depict their different behaviours and hinder certain ethnic group ventures or growth into entrepreneurship [12], [13]. In reality, youths must have their own capabilities and it is depending on how they manage their business resources in order to success in business. At the same time, young entrepreneurs also need to noticed that it necessity for them to links with environment in order to strengthen access to markets and resources management. It is because, not all of them have the capabilities and adequate sources to get the opportunity given [14]. This is the main challenge faced by young entrepreneurs in Malaysia where the government and society should take action to ensure the success of youth in entrepreneurship [11].

Certain researchers have used various factors and theories in determining the success among young generation. Those factors and theories had been debated from time to time [15]. From that, it can be concluded that youth who wishes to become an entrepreneur has to review and evaluate his or her own decision and readiness to venture into business. Understanding their entrepreneurial drives is doubly important and some external factors such as financing, training, and economics conditions are also the critical factors in achieving business success [10]. It is because, the development of internal and external resources or factors will leads to business growth and successful in advanced and emerging nations includes Malaysia [13]. Studied by [16] identified that the most important part for entrepreneurs to survival or growth their business are resources. Manages resources effectively from various sources is crucial for business not only for financial wealth, but also for others outcome like fulfilment of personal needs, and society acceptable probability of having similar interests or better. Followed with that, youth need to bring contact to strengthen their business performance. Thus, supported study by [11] proved that well managed of the business resources and able to conduct business relation can impart legitimacy on business growth as well as create new ventures [17]. Present study will develop entrepreneur's success model based on the combination of various resources for development of resource orchestration and the role of social network competence in achieving superior performance among young entrepreneurs in Malaysia.

\section{Literature Review}

According to United Nation, the definition of youth is young people with aged between 15 to 24 years old. However, in Malaysia, a study by [6] states that youth is comprised of those aged between 15 to 40 years. This is similar to the definition that had been highlighted by Malaysian Youth Council in 2007, where young people aged 15 years and above, which is not more than 40 years will be categorized as a youth. At this age, they have mature thinking, open-minded and also have high competitiveness [1]. In addition, some entrepreneurial researchers have identified that a good entrepreneur has the characteristics such as personality, socio-cultural, diversity of business activities as well as a strong will to develop their business [6]. This feature is not only owned by entrepreneur's adults, but is also owned by young entrepreneurs. In other words, these are the characteristics that distinguish whether a youth is an entrepreneur or not [6].

There are few of studies based on youth entrepreneurship. For examples, [18] summarizes the study by [6] which is conducted a research study focusing on entrepreneurship of young people age range between 25 to 40 years olds in Malaysia. From the finding of that studies, it is found that the impact of sociological environment such as religiosity and cultural values influence the development of entrepreneurship. At the same time, the psychological factors like risk-taker, hardworking, have a desire to continue learning and dare to challenge also have significant effect toward the growth of business new venture among youth in Malaysia [6]. 
Moreover, most studies found that the youth are now more interested in venturing into the retail and trading sectors, rather than agricultural sector. As support, study by [4] found that youth did not attract to involve in agriculture sector because this sector "does not seen as attractive as factories and other commercial establishment". Finding from past studied by [19] on youth inclination towards agricultural entrepreneurship also proved that involvement of youth in agricultural sector was declining because they believe that agricultural sector is not suitable for them. Only youth who have the background of the families involved in the agricultural sector are keen to be active in this sector [19].

There are lots of programs, training, research and other activities related to young entrepreneurial conducted by "Ministry of Youth and Sports Malaysia and The Institute of Youth Development Research Malaysia (Institute Penyelidikan Pembangunan Belia Malaysia/IPPBM)". Based on Ninth Malaysia Plan for 2006 to 2010, the government has also organized entrepreneurship program with the objective to identify talents among entrepreneurs at the school level up to the university level. There are about "RM5.4 billion has been allocated in the Ninth Malaysia Plan (RMK9) by the government for youth development through various youth skills training and leadership" as stated in [20]. Continuation of previous Malaysia Plan, the budget for 2014 saw continued focus on supporting entrepreneurship from various points including heavily investing, nurturing and producing more innovative entrepreneurs [11]. Among the initiatives was the establishment of the Malaysian Global Innovation and Creative Centre (MaGIC), a one-stop centre to enhance entrepreneurship and support companies involved in creative multimedia. Another initiative is by Yayasan Innovasi Malaysia (YIM) to bring innovation in Malaysia country to the next level, focuses on mainstreaming a new culture of innovation among SMEs, NGOs and communities. Thus, Gathering of Rising Entrepreneurs Act Together (GREAT) also had been lunched by Prime Minister, Datuk Seri Najib Tun Razak, which is a movement acts as a platform for aspiring entrepreneurs to interact with one another as well as to meet established entrepreneurs and potential investors [11].

Furthermore, [21] stressed that the success of young entrepreneurs is an important aspect in the development of the national economy. This is because the younger generation is an important asset that contributes to a country's industrial expansion. It is also suggested by [18] that if they have features such as open-minded, dare to take risks and high-spirited, the young generations will be good source of entrepreneurs to introduce the changes in our economy. Therefore, it is important for this current study to explore and investigate what and how youth orchestrate the abundance of resources available and how the contacts/networking help them for business success based of difficulties face by youth entrepreneurs, identified by [11].

\section{Methodology}

For methodological aspect of this study, descriptive-correlation research will be employed as it is the most appropriate method in this study. The nature of this study is useful to capture the opinion of the respondents based on quantitative approaches and highlighted the relationships among variables by accessing the degree to which the variables co-vary. It is because, the details of research flow and variables involved will be explained based on findings of this study [22]. From that, the present study will clearly indicates that, the factors of survivability, cultural orientation, economic and political-legal will lead to development of resource orchestration, and then, will contribute to success. Therefore, the role of social network competence will enhance the relationship between resource orchestration and entrepreneur's success. From past literature, measurements of variables of this study shown on Table 1:

Table 1: Measurement of Variables

\begin{tabular}{|c|c|}
\hline Concept & \begin{tabular}{c} 
Dimensions/Theory \\
\hline Survivability
\end{tabular} \\
\hline Cultural Orientation & $\begin{array}{c}\text { Individual characteristics (attitudes toward risk, independent) and mind-set toward success } \\
\text { (antecedent factor for resource orchestration) }\end{array}$ \\
\hline Economic & Religious, norms and belief (antecedent factor for resource orchestration) \\
\hline Political-Legal & Financial institutions and taxation (antecedent factor for resource orchestration) \\
\hline Resource Orchestration & Government and regulation (antecedent factor for resource orchestration) \\
\hline Social Network Competence & Knowledge, trust and innovation-based relationship (Sociological entrepreneurship theory) \\
\hline Entrepreneurs' Success & Creating wealth and values (beneficial for individual, organization and societal) \\
\hline
\end{tabular}

\section{Conclusion}

As conclusion, many scholars have argued that entrepreneurial activity is a major contributor to economic development and growth, creating new jobs and enhanced market valuations. Some have argued that entrepreneur's activities targeting areas of social need could lead to a marketization of non-profit organizations in ways that do not truly satisfy societal needs. However, entrepreneurial activity can also give beneficial for community and society. For example, an enhanced focus on and resources allocated to entrepreneurial activity could increase the opportunities to pursue entrepreneurial undertakings. Meanwhile, it also can help to build 
new economic, social, institutional, and cultural environments. Someone who is seriously wanted to be involved in entrepreneurship must have three essential elements within them which are identifies the business opportunities based on what they have run, always moving as a team, and also able to find the right resources for their business growth. From that, the combination of capabilities with the availability of business resources will lead to success if the resources are utilized properly, strategically and innovatively.

The question of why some of young entrepreneurs especially youth are very successful and some are not, is very difficult to answer and have long been debated in a developing country. Empirical research does not find strong evidence supporting this approach. There are still unclear factors that make these entrepreneurs more successful than their counterparts. Studies on youth entrepreneur success are still not much evidence to support where the earlier studies on entrepreneur's success are related to general issues of entrepreneurship. No conclusive evidence has been produced to validate the belief. Young entrepreneurs in Malaysia too faced enormous pressures as the nation integrates more into the world economy. Hence, a thorough understanding of how youth entrepreneurs utilize their resources, thus how they bring contacts is important, because this will lead to the development of new tools, such as (1) tools for business to improve their innovation and growth processes and, (2) tools for governments to develop new policies to support and direct economic growth.

\section{References}

[1] C. P. Kamal, H. Azimi, B. A. Samah, A. I. Ismi, and J. L. D’Silva, Rural Malay involvement in Malaysian herbal entrepreneurship, Asian Social Science, 10 (2), 2013, 202-208.

[2] H. Nor Hidayah, J. Norchahaya, and M. Marinah, Factors influencing the involvement of Malaysian youth in entrepreneurship, TeSSHI 2014- Technology, Science Social Sciences, Humanities, 4, 2014, 645-655.

[3] N. Othman and S. Ishak, Attitude towards choosing a career in entrepreneurship amongst graduates, European Journal of Social Science, 10(3), 2009, 419-434.

[4] A. A. Abdullah and N. N. Sulaiman, Factors that influence the Interest of youths in agricultural entrepreneurship, International Journal of Business and Social Science, 4(3), 2013, 288-302.

[5] T. T. Mavasa, Appraisal of Enterprise Development Finance Programmes of the National Youth Development Agency, master diss., National Youth Development Agency, Stellenbosch University, 2014.

[6] K. L. Chan, S. Selvadurai, and A. H. Bahiyah, "Malay youth entrepreneurship in Malaysia : an empirical update," Soc. Sci., vol. 2, no. 2, pp. 55-67, 2009.

[7] N. Amran, Labour force statistics, Malaysia, January 2015, 1-5

[8] Central Bank of Malaysia, Malaysia bankruptcies 1998-2016, Trading Economic, 2016. [Online]. Available: http://www.tradingeconomics.com/malaysia/bankruptcies. [Accessed: 19-Mar-2016].

[9] The Star Online, Becoming bankrupt before 35, Star Publications (Malaysia) Berhad, 2015. [Online]. Available: http://www.thestar.com.my/news/nation/2015/06/22/becoming-bankrupt-before-35-worrying-trend-of-about-25000-gen-y-msiansin-debt-over-the-last-five-ye/. [Accessed: 19-Mar-2016].

[10] J. Haron, Entrepreneurial drives and business performance of Malaysian entrepreneurs, doctoral diss., Faculty of Business Management Universiti Teknologi Mara, 2010

[11] A. Sheikh Ghazali, Entrepreneurship and innovation : Empowering the youth, in 28th CACCI Conference, $2014,1-34$.

[12] M. Zimmerman and H. Chu, Motivation, success, and problems of entrepreneurs in Venezuela, Journal of Management Policy and Practice, 14 (2), 2013, 76-90.

[13] Y. Sefiani, Factors for Success in SMEs: A perspective from Tangier, Faculty of Business, Education and Professional Studies, University of Gloucestershire, 2013.

[14] M. Zain and S. I. Ng, The impacts of network relationships on SMEs' internationalization process, Thunderbird International Business Review, 48(2), 2006, 183-205.

[15] K. N. Simpeh, Entrepreneurship theories and empirical research: A Summary review of the literature, European Journal Of Business and Management, 3(6), 2011, 1-9.

[16] M. A. Hitt, R. D. Ireland, D. G. Sirmon, and C. A. Trahms, Strategic entrepreneurship: Creating value for individuals, organization, and society, Academic Management Perspective, 25(2), 2011, 57-76.

[17] W. Nowiński and A. Rialp, The impact of social networks on perceptions of international opportunities, Journal of Small Business Management, 2015, 1-17.

[18] M. Nguyen and A. Phan, Entrepreneurial traits and motivations of the youth - an empirical study in Ho Chi Minh City - Vietnam, International Journal of Business and Social Science, 5(1), 2014, 53-62.

[19] M. N. Nor Amna A'liah, N. M. M. Nik Rozana, and M. Mohd Khairul Hafifi, Youth inclination towards agricultural entrepreneurship, Economic and Technology Management Review, 10a, 2015, 47-55.

[20] Economic Report, Economic management and prospects. Economic Report 2012/2013, 2013, 1-30.

[21] R. Fisher, A. Maritz, and A. Lobo, Evaluating entrepreneurs' perception of success, International Journal of Entrepreneurial Behaviour \& Research, 20(5), 2014, 478-492, 2014.

[22] J. W. Creswell, Research design: Qualitative, quantitative, and mixed methods approaches (Sage publications, 2013).

[23] A. Hyytinen, M. Pajarinen, and P. Rouvinen, Does innovativeness reduce startup survival rates?, Journal of Business Venturing, 30(4), 2015, 564-581.

[24] A. G. A. Ilhaamie, B. Siti Arni, M. Mohd Rizal, C. H. Rosmawani, and M. Hasan Al-Banna, Motivation of muslim women entrepreneurs in Malaysian SMEs, 4th Int. Conference on Management., 2014, 217-228.

[25] S. Tehseen, S. Sulaiman, T. Ramayah, and K. Gadar, An intra-cultural study of entrepreneurial competencies and SMEs business success in whole sale and retail Industries of Malaysia: A conceptual model, Review Of Integrative Business Research and Economics, 4(3), 2015, 33-48.

[26] M. Z. A. Abdul Rashid and J. A. Ho, Perceptions of business ethics in a multicultural community: The case of Malaysia," J. Bus. Ethics, 43(1-2), 2003, 75-87.

[27] Y. Gürol and N. Atsan, Entrepreneurial characteristics amongst university students: Some insights for entrepreneurship education and training in Turkey, Education + Training., 48(1), 2006, 25-38.

[28] J. M. Jasra, A. I. Hunjra, A. U. Rehman, R. I. Azam, and M. A. Khan, Determinants of business success of small and medium 
enterprises, International Journal of Business and Social Science, 2(20), 2011.

[29] F. Chirico, D. G. Sirmon, S. Sciascia, and P. Mazzola, Resource orchestration in family firms: Investigating how entrepreneurial orientation, generational involvement, and participative strategy affect performance, Strategic Entrepreneurship Journal, 5(4), 2011, 307-326.

[30] F. D. Oke, The effect of social network on women entrepreneurs in Nigeria: A case study of Ado-Ekiti small scale enterprise, International Journal of Education and Research, 1(11), 2013, 1-14.

[31] P. Berrone, C. Cruz, L. R. Gomez-Mejia, and M. Larraza-Kintana, Socioemotional wealth and corporate responses to institutional pressures: Do family-controlled firms pollute less?, Administrative Science Quarterly, 55(1), 2010, 82-113.

[32] M. J. Gorgievski, E. M. Ascalon, and U. Stephan, Small business owners' success criteria, a values approach to personal differences, Journal of Small Business Management, 49(2), 2011, 207-232. 